\title{
カルボプラチン投与量算出における Calvert式利用に関する実態調査
}

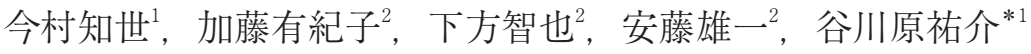 \\ 慶應義塾大学医学部臨床薬剤学 1 \\ 名古屋大学医学部附属病院化学療法部
}

\section{Survey on the Usage of the Calvert Formula to Calculate AUC-based Carboplatin Dosing in Japan}

\begin{abstract}
Chiyo K Imamura', Yukiko Kato², Tomoya Shimokata², Yuichi Ando ${ }^{2}$ and Yusuke Tanigawara*1 Department of Clinical Pharmacokinetics and Pharmacodynamics, School of Medicine, Keio University ${ }^{1}$, Department of Clinical Oncology and Chemotherapy, Nagoya University Hospital ${ }^{2}$
\end{abstract}

$\left[\begin{array}{l}\text { Received July 22, } 2015 \\ \text { Accepted August 20, } 2015\end{array}\right]$

The renal clearance of carboplatin, which is a second-generation platinum compound, is correlated with the glomerular filtration rate (GFR). As the area under the concentration-time curve (AUC) of free carboplatin is related with efficacy and toxicity following carboplatin administration, carboplatin dosing is defined as a target AUC and generally calculated by the Calvert formula according to the patient's GFR. We conducted a survey on the usage of the Calvert formula to clarify the current situation in Japan. As a result, the value of creatinine clearance (CLcr), which is higher than GFR due to the tubular secretion of creatinine, has been used as a substitute for GFR for the Calvert formula without appropriate correction in 71 of 109 institutions, where CLcr estimated by a Cockcroft-Gault equation and/or obtained by 24-h urinary collection are used. On the other hand, body surface area-indexed values of renal function have been directly used without conversion to individual values in 42 of 71 institutions, where GFR estimated by a Japanese equation and/or CLcr estimated by a Jelliffe equation are used. It was found that the desired dosing of carboplatin has not been administered to patients in a number of institutions. Back to the original concept of the Calvert formula, it is reasonable to use a GFR estimated by the Japanese equation and converted to an individual value. In addition, we need to assess tolerability following carboplatin administration and discuss the appropriateness of the starting dose for each patient without being overly reliant on the dose obtained by the Calvert formula.

Key words — carboplatin, CBDCA, Calvert formula, glomerular filtration rate (GFR), creatinine clearance

\section{緒 言}

カルボプラチン（carboplatin: CBDCA）はシス プラチンの抗腫瘍効果を弱めることなく, 腎障害, 聴覚障害, 未梢神経障害などの非血液毒性を軽減 することを目的に開発された白金製剤であり，肺 がんや婦人科がんなどの標準治療として多くの患 者に用いられている. ${ }^{1-3)}$ CBDCA の開発時に得ら れた薬物動態データより, その消失クリアランス が糸球体濾過量（glomerular filtration rate: GFR）

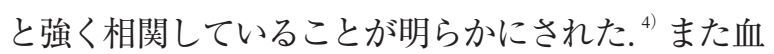
漿タンパク質と結合していない遊離形白金濃度か ら求めた遊離形 CBDCA の血中濃度－時間曲線下 面積 (area under the concentration-time curve: AUC)

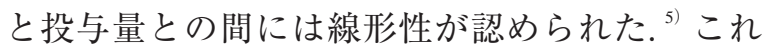
ら CBDCA の薬物動態的特徴に基づいて, 目標 AUC 值と患者の GFR 值から CBDCA の用量を求 める式が Calvert らにより構築された（式 1). ${ }^{6}$

\footnotetext{
*テ160-8582 東京都新宿区信濃町35
} 
Dose $(m g)=$ target AUC $\times($ GFR +25$) \cdots \cdots \cdots$ 式 1

CBDCA の腫瘍縮小効果や骨髄抑制は遊離形 CBDCA の AUC と相関し, 奏効割合は AUC 值が 4〜 7 $\mathrm{mg} \cdot \mathrm{min} / \mathrm{mL}$ 以上でほぼ一定となり最大効果 が得られるものの, 白血球減少や血小板減少の発 現率は AUC 值が $17 \mathrm{mg} \cdot \mathrm{min} / \mathrm{mL}$ までの範囲でシ グモイド状に増加することから, ${ }^{7)}$ 多くの固形が んの標準治療における CBDCA の投与量は「目標 AUC 值が 4 $6 \mathrm{mg} \cdot \mathrm{min} / \mathrm{mL} 」$ と設定されており, その用量算出において Calvert 式が広く用いられ ている.

Calvert 式で用いる腎機能值 GFR を実測するた めのイヌリンクリアランス検査は煩雑なため患者 および医療者ともに負担が大きいことから，米国 を中心に Calvert 式の GFR 值にクレアチニンクリ アランス（creatinine clearance: CLcr）值を代用し て CBDCA 量が算出されてきた. しかしクレアチ ニンはその腎排泄において糸球体濾過に加えて尿 細管分泌を受けるため CLcr 值は GFR 值より大き く, Calvert 式への CLcr の代用により CBDCA 量 が過剩に見積もられてしまうことが指摘されてい る. ${ }^{8-10)}$ 一方, 2008 年に日本腎臟学会より「日本 人の GFR 推算式」が発表 ${ }^{11)}$ されて以降, 本推算式 から得られる GFR 推算值 (estimated GFR: eGFR) が Calvert 式に用いられるようになってきた。しか し本推算式で得られる eGFR 值は標準体表面積 $1.73 \mathrm{~m}^{2}$ あたりの值 $\left(\mathrm{mL} / \mathrm{min} / 1.73 \mathrm{~m}^{2}\right)$ であるため, Calvert 式に用いる際には患者の体表面積（body surface area: BSA）值を用いて「BSA／1.73」を乗 じて個々の患者の GFR 值 $(\mathrm{mL} / \mathrm{min} / \mathrm{body})$ を求 めなければならない。これら Calvert 式に用いる 腎機能值の問題点を踏まえ，その使用における現 状を明らかにすることを目的として，全国のがん 専門薬剂師およびがん指導薬剤師を対象に「カル ボプラチンの投与量算出に関する実態調査」を 行った.

\section{方 法}

\section{1. 対象}

一般社団法人日本医療薬学会認定のがん専門薬
剤師およびがん指導薬剤師を対象とした。なお， 上記の認定薬剂師が複数名所属する医療機関にお いては, 1 名のみが回答を行った.

\section{2. 期間}

2014 年 1 月 6 日〜 1 月 22 日の 17 日間を回答期 間とした。

\section{3. 調查票と回答法}

Google フォーム（Google Inc，カリフォルニア 州，アメリカ合衆国）にて調査票を作成しウェブ 調査を行った。なお対象者の所属医療機関のイン ターネット環境により本調查票の URL にアクセ スできない場合には, 紙版の調査票と回答を FAXにて, もしくはPDF として電子メール添付に て送受信した。同一医療機関から複数名より回答 された場合の重複集計を避けるため, 回答欄に医 療機関名と回答者名を設けたが, 結果の公表時に はこれらを表示しないことを事前に対象者に通知 した。

\section{4. 設問の概要}

設問は，(1)所属医療機関におけるCBDCA の投 与量決定法，(2) Calvert 式で算出する際に用いる 腎機能值，(3)過量投与を防ぐための上限值または 下限值設定の有無, (4)投与量算出における腎機能 変動の反映，に関する内容とし回答は多肢選択と した。なお，(2)に関しては各医療機関での全体的 な傾向ではなく CBDCA の使用頻度が高い診療科 である呼吸器内科, 呼吸器外科, 婦人科での状況 を尋ねた。調査票を表 1 として示す。また調查 時に選択肢として挙げた Cockcroft-Gault 式, ${ }^{22}$ Jelliffe 式, ${ }^{13)}$ 日本腎臟学会による日本人の GFR 算 出式 ${ }^{11)}$ といった血清クレアチニン（ $\mathrm{Scr} ）$ 值に基 づく腎機能指標值推算式を表 2 に示した.

\section{結 果}

\section{1. 回答率}

がん専門薬剤師およびがん指導薬剤師の所属す る全国の医療機関 210 施設のうち, 112 施設より 回答を得た. 
表 1 「カルボプラチンの投与量算出に関する実態調査」の調査票

カルボプラチンの投与量について

（1）貴院では日常診療において, カルボプラチンの投与量は次のいずれの方法で決定されていますか.

$\begin{array}{ll}\square \text { 目標 AUC 值を用いて Calvert 式より算出 } & \rightarrow \text { 質問 (2) 以降へ } \\ \square \text { 体表面積あたりの投与量 }\left(\mathrm{mg} / \mathrm{m}^{2}\right) & \rightarrow \text { 終了 } \\ \square \text { レジメンごとに異なる } & \rightarrow \text { 質問 (2) 以降へ } \\ \square \text { その他（ } & \rightarrow \text { 質問 (2) 以降へ }\end{array}$

(2) Calvert 式で用いる GFR は次のいずれの方法より得ていますか

以下, 各診療科（呼吸器内科, 呼吸器外科, 婦人科)に拈いて最もよく用いられている方法を 1 つ選択してください.

1) 呼吸器内科

$\square$ 実測イヌリンクリアランス

$\square$ 実測 24 時間クレアチニンクリアランス

$\square$ Cockcroft-Gault 式

$\square$ Jelliffe 式

$\square$ 日本腎臓学会による「日本人の GFR 推算式」

わからない

口呼吸器内科がない

その他 (

2) 呼吸器外科
実測イヌリンクリアランス
実測 24 時間クレアチニンクリアランス
$\square$ Cockcroft-Gault 式
$\square$ Jelliffe 式
$\square$ 日本腎臓学会による「日本人の GFR 推算式」
$\square$ わからない
$\square$ 呼吸器外科がない
$\square$ その他

3) 婦人科

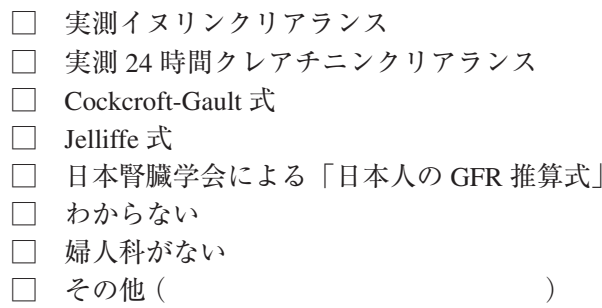

（3）GFR として「実測 24 時間クレアチニンクリアランス」または「Cockcroft-Gault 式」より得た值を用いる場合, 血清クレアチニン 值の補正（+0.2）をしていますか.

$\square$ 補正している

$\square$ 補正していない

$\square$ 「実測 24 時間クレアチニンクリアランス」や「Cockcroft-Gault 式」を用いていない

（4）GFR として「日本人の GFR 推算式」または「Jelliffe 式」より得た値を用いる場合，患者の体表面積による補正（体表面積／1.73） をしていますか.

$\square$ 補正している

$\square$ 補正していない

$\square$ 「日本人の GFR 推算式」や「Jelliffe 式」を用いていない

（5）カルボプラチンの過量投与を防ぐために投与量算出時に上限值または下限值を設定（capping）していますか.

$\square$ 設定している

～設定している項目については，その「上限值/下限值」をご記入ください
GFR: 上限值
$\mathrm{GFR}+25:$ 上限值
$\mathrm{mL} / \mathrm{min}$
投与量 : 上限值
血清クレアチニン: 下限值

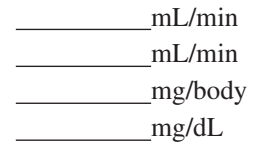

設定していない

（6） 2 回目以降のカルボプラチン投与量は，その時の腎機能により更新していますか.
$\square$ 毎回更新している
更新していない
たまに更新している 
表 2 血清クレアチニン值に基づく腎機能指標值推算式

\begin{tabular}{|c|c|}
\hline Cockcroft-Gault 式 & $\mathrm{eCLcr}(\mathrm{mL} / \mathrm{min})=\frac{(140-\mathrm{Age}) \times \mathrm{BW}}{72 \times \mathrm{Scr}}\left(\begin{array}{c}\text { 女性の場合 } \\
\times 0.85\end{array}\right)$ \\
\hline Jelliffe 式 & $\mathrm{eCLcr}\left(\mathrm{mL} / \mathrm{min} / 1.73 \mathrm{~m}^{2}\right)=\frac{98-0.8 \times(\text { Age }-20)}{\mathrm{Scr}}\left(\begin{array}{c}\text { 女性の場合 } \\
\times 0.9\end{array}\right)$ \\
\hline 日本人の GFR 推算式 & $\mathrm{eGFR}\left(\mathrm{mL} / \mathrm{min} / 1.73 \mathrm{~m}^{2}\right)=194 \times \mathrm{Scr}^{-1.094} \times \operatorname{Age}^{-0.287}\left(\begin{array}{c}\text { 女性の場合 } \\
\times 0.739\end{array}\right)$ \\
\hline
\end{tabular}

\section{CBDCA の投与量決定法（図 1)}

CBDCAの投与量は, 112 施設中 86 施設 $(76.8 \%$ ) が目標 AUC 值を用いて Calvert 式により算出して いると回答し，レジメンごとに異なるとの回答が 26 施設（23.2\%）であった。また，添付文書の用 量単位である体表面積あたりの投与量 $\left(\mathrm{mg} / \mathrm{m}^{2}\right)$ によるレジメンのみの医療機関はなかった。

\section{Calvert 式で CBDCA 投与量を算出する際 に用いる腎機能値}

（1）診療科による違い（表 3）

(1)呼吸器内科

Calvert 式の GFR 值として Cockcroft-Gault 式よ り得られる estimated CLcr (eCLcr) 值を用いて いる施設が最も多く（80 施設， $71.4 \%)$, 次いで

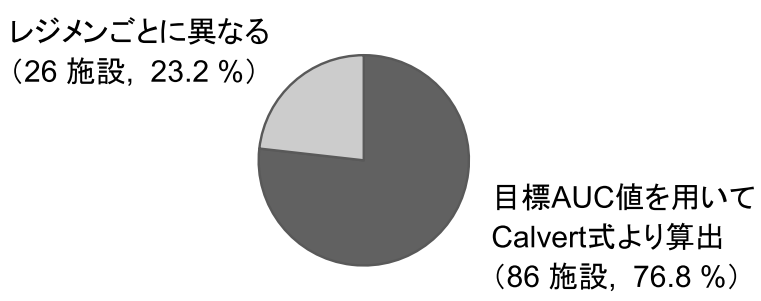

図 1 カルボプラチンの投与量決定法
実測 24 時間 CLcr（11 施設，9.8\%)，Jelliffe 式よ り得られる eCLcr 值（6 施設, 5.4\%), 日本人の GFR 推算式より得られる eGFR 值（4 施設, 3.6\%) であった。

\section{(2)呼吸器外科}

Calvert 式の GFR 值として Cockcroft-Gault 式よ り得られる eCLcr 值を用いている施設が最も多く (58 施設, $51.7 \%)$, 次いで Jelliffe 式より得られ る eCLcr 值（6 施設, 5.4\%), 実測 24 時間 CLcr（5 施設, $4.5 \%)$, 日本人の GFR 推算式より得られ る eGFR 值（1 施設， $0.9 \%$ ）であった。

\section{(3)婦人科}

Calvert 式の GFR 值として Cockcroft-Gault 式よ り得られる eCLcr 值を用いている施設が最も多く (54 施設, $48.2 \%)$, 次いで Jelliffe 式より得られる eCLcr 值（29 施設, 25.9\%), 実測 24 時間 CLcr（15 施設， $13.4 \%)$ ，日本人の GFR 推算式より得られ る eGFR 值（2 施設, $1.8 \%$ ) であり, 呼吸器内科 や呼吸器外科と比べて Jelliffe 式より得られる eCLcr 值を代用しているケースが多かった 。

表 3 Calvert 式でカルボプラチン投与量を算出する際に用いる腎機能值（112 施設）

\begin{tabular}{|c|c|c|c|c|}
\hline 選択肢 & 得られる腎機能值 & $\begin{array}{l}\text { 呼吸器内科 } \\
\text { 施設数 (\%) }\end{array}$ & $\begin{array}{l}\text { 呼吸器外科 } \\
\text { 施設数 }(\%)\end{array}$ & $\begin{array}{c}\text { 婦人科 } \\
\text { 施設数（\%) }\end{array}$ \\
\hline 実測イヌリンクリアランス & GFR $(\mathrm{mL} / \mathrm{min})$ & $0(0)$ & $0(0)$ & $0(0)$ \\
\hline 実測 24 時間クレアチニンクリアランス & CLcr $(\mathrm{mL} / \mathrm{min})$ & $11(9.8)$ & $5(4.5)$ & $15(13.4)$ \\
\hline Cockcroft-Gault 式 & eCLcr $(\mathrm{mL} / \mathrm{min})$ & $80(71.4)$ & $58(51.7)$ & $54(48.2)$ \\
\hline Jelliffe 式 & $\mathrm{eCLcr}\left(\mathrm{mL} / \mathrm{min} / 1.73 \mathrm{~m}^{2}\right)$ & $6(5.4)$ & $6(5.4)$ & $29(25.9)$ \\
\hline 日本人の GFR 推算式 & eGFR $\left(\mathrm{mL} / \mathrm{min} / 1.73 \mathrm{~m}^{2}\right)$ & $4(3.6)$ & $1(0.9)$ & $2(1.8)$ \\
\hline わからない & - & $0(0)$ & $2(1.8)$ & $2(1.8)$ \\
\hline 当該診療科なし & - & $11(9.8)$ & $24(21.4)$ & $10(8.9)$ \\
\hline 当該診療科では化学療法実施せず & - & $0(0)$ & $16(14.3)$ & $0(0)$ \\
\hline
\end{tabular}


A

「実測24時間クレアチニンクリアランス」や

「Cockcroft-Gault式」を用いていない

(3 施設, $2.7 \%$ )

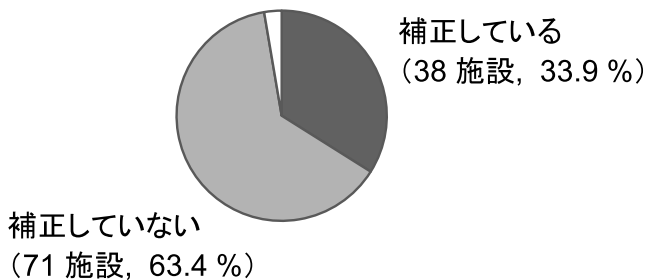

B

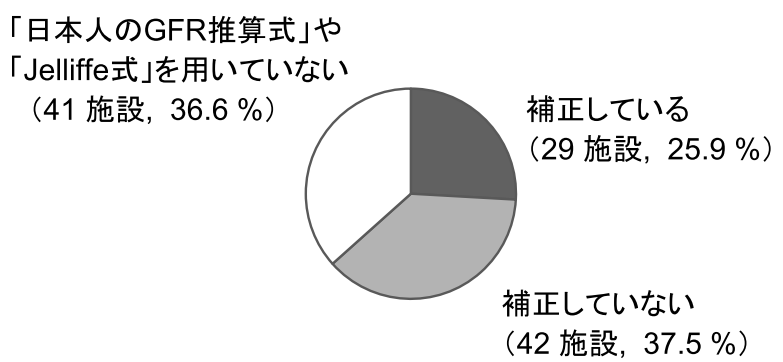

図 2 Calvert 式に用いる腎機能值の取り扱い

A：血清クレアチニン值の補正， B：標準体表面積あたりの値の補正。

（2）血清クレアチニン值の補正（図 2A）

実測 24 時間 CLcr 值または Cockcroft-Gault 式 より得られる eCLcr 值を GFR に代用しているの は 109 施設（97.3\%）であり, Scr 值に $0.2 \mathrm{mg} / \mathrm{dL}$ を加えて補正を行っているのは 38 施設 $(33.9 \%)$, 補正を行っていないのは 71 施設 $(63.4 \%)$ であった .

（3）標準体表面積あたりの值の補正（図 2B）

日本人の GFR 推算式より得られる eGFR 值お よび Jelliffe 式より得られる eCLcr 值を Calvert 式 の GFR 值として用いているのは 71 施設 (63.4\%) であり,「BSA／1.73」を乗じて個々の患者の腎 機能（mL/min/body）を算出したうえでCBDCA 量を求めているのは 29 施設 $(25.9 \%)$ であり, 42 施設 $(37.5 \%)$ において標準体表面積 $1.73 \mathrm{~m}^{2}$ あたりの值 $\left(\mathrm{mL} / \mathrm{min} / 1.73 \mathrm{~m}^{2}\right)$ がそのまま Calvert 式に用いられていた。

\section{4. 過量投与を防ぐための上限値または下限値設 定の有無（図 3）}

CBDCAの過量投与を防ぐために投与量算出時 に何らかの上限值もしくは下限值を設定している のは 112 施設のうち 54 施設 $(48.2 \%)$ であった . なお複数回答可として尋ねた設定值については, GFR 上限值が 13 施設, GFR +25 の上限值が 11 施設, 投与量の上限值が 4 施設, Scr 下限值が 2 施設であった（表 4).
設定していない (58 施設, $51.8 \%$ )

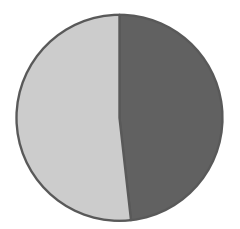

設定している

(54 施設, $48.2 \%)$
図 3 カルボプラチン過量投与を防ぐための上限值 または下限值設定の有無

表 4 カルボプラチン過量投与を防ぐために設定 されている項目と設定值の例（複数回答可）

\begin{tabular}{lcll}
\hline \hline \multicolumn{1}{c}{ 項目 } & 施設数 & \multicolumn{2}{c}{ 設定值の例 } \\
\hline GFR & 13 & 上限值 & $125 \mathrm{~mL} / \mathrm{min}$ \\
\hline $\mathrm{GFR}+25$ & 11 & 上限值 & $150 \mathrm{~mL} / \mathrm{min}$ \\
\hline \multirow{3}{*}{ 投与量 } & & & $600 \mathrm{mg}(\mathrm{AUC} 4)$ \\
& 4 & 上限值 & $\begin{array}{l}750 \mathrm{mg}(\mathrm{AUC} 5) \\
900 \mathrm{mg}(\mathrm{AUC} 6)\end{array}$ \\
\hline 血清クレアチニン & 2 & 下限值 & $0.6 \mathrm{mg} / \mathrm{dL}, 0.7 \mathrm{mg} / \mathrm{dL}$
\end{tabular}

\section{5. 投与量算出における腎機能変動の反映（図 4)}

CBDCA 投与開始後の腎機能の変動を投与量に 反映するために用量の再計算を毎回行っているの は 112 施設のうち 50 施設 $(44.6 \%)$ ，たまに更新 (再計算) しているのは 13 施設 $(11.6 \%)$ であり, 更新せずに初回投与量を継続しているのは 49 施 設 $(43.8 \%)$ であった。

\section{考察}

CBDCA の用法・用量は添付文書に「体表面積

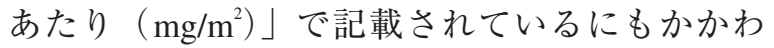


更新していない (49 施設, $43.8 \%$ )

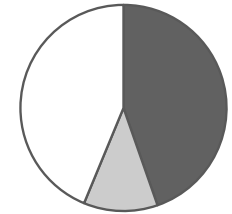

毎回更新している (50 施設, $44.6 \%)$

たまに更新している (13 施設, $11.6 \%)$

図 4 カルボプラチン投与量算出における腎機能変動 の反映

らず，CBDCAを含む多くのレジメンでは「目標 AUC 值」として投与量が規定されている. 非小 細胞肺がんに対するパクリタキセル $200 \mathrm{mg} / \mathrm{m}^{2}$ と の併用療法では AUC 6, ${ }^{1)}$ 卵巣がんに対するパク リタキセル 175 $180 \mathrm{mg} / \mathrm{m}^{2}$ との併用療法では AUC 5〜 6 $6^{2}$ が標準治療とされており，これらは Calvert 式で算出された用量で日本人に打ける有 効性と安全性が大規模臨床試験にて検証されてい る. ${ }^{14,15)}$ 本調查において日常診療での CBDCA 投与 量の決定法を尋ねたところ，レジメンごとに異な るとの回答だった 26 施設も含め, 回答の得られた 全 112 施設でCalvert 式が用いられていた（図 1). なおレジメンごとに異なるとの回答には，婦人科 におけるChatelut 式の使用があった．Chatelut 式 は 1995 年に発表された CBDCA クリアランスの推 算式であり，本式より得られたクリアランス值を 目標 AUC 值に乗じることで CBDCA 投与量が求 められる. ${ }^{16)}$ またほとんどの施設において診療科 の意向に基づく方法で CBDCA の用量算出が行わ れており，薬剤師が診療科ごとで異なる算出法に 対応している現状が明らかとなった。

Calvert 式により CBDCA 投与量を求める場合 には，通例的に GFR 值に CLCr 值を代用すること が行われてきた。クレアチニンはその腎排泄にお いて糸球体濾過のみならず尿細管分泌も受けるた め CLcr 值は GFR 值より大きい $(\mathrm{CLcr}>\mathrm{GFR})^{17)}$ ことから，Calvert 式における GFR 值に CLcr 值 を代用すると CBDCA 量は過剩に見積もられてし まう。しかしながら米国においては，従来より Scr 測定法として実施されていたヤッフェ法が非 特異的反応のため, 真の值より約 $0.2 \mathrm{mg} / \mathrm{dL}$ 高い Scr 值が臨床現場で用いられてきた．従ってこの Scr 值から求められる CLcr 值は, その過剩分の 0.2 $\mathrm{mg} / \mathrm{dL}$ が尿細管から分泌されるクレアチニン量 （CLcr 全体量の 10〜20\%）を相殺して, 結果と して CLcr 值が GFR 值に近似するという状況をも たらしていた。つまりこのような米国の状況下で は Calvert 式の GFR 值に対し CLcr 值の代用が許 容されていたと言える.Scr 值の測定法にはヤッ フェ法と酵素法があり，酵素法は特異的反応であ るため真の值が得られる。 日本では 1990 年代半 ばよりほとんどの医療機関において酵素法が採用 されているため, Scr 值は正確ではあるものの CLcr 值を GFR 值として代用する際には, Scr 值 に 0.2 を加えてヤッフェ法によるScr 值に換算す る補正を行う必要性が提唱されてきた. ${ }^{8-10)}$ 補正を 行わない場合の Cockcroft-Gault 式による eCLcr 值 はイヌリンクリアランス検査による実測 GFR 值 に比べて $12.5 \%$ 高值であり，また 24 時間蓄尿に よる実測 CLcr 值は $24.2 \%$ 高値となる. ${ }^{18)}$ なお日本 腎臓学会からは「eGFR $=0.719 \times$ 実測 CLcr」と いう関係式が提示されている. ${ }^{10)}$ 本調查において Calvert 式の GFR 值に Cockcroft-Gault 式より求め た eCLcr 值もしくは 24 時間蓄尿による実測 CLcr 值を代用している医療機関は 109 施設に及び，そ のうち Scr 值の補正を行っているのはわずか 38 施設であり，6割以上の施設において意図した量 より CBDCA が過剩に投与されている現状が明ら かになった（図 2A）.

GFR 值を実測するイヌリンクリアランス検査 は煩雑なため, 患者の Scr 值と年齢から GFR を 求める推算式が腎疾患の診断においては臨床で広 く用いられている.1999年に米国にて発表され た Modification of Diet in Renal Disease (MDRD) 式 ${ }^{19)}$ はヤッフェ法での Scr 值に基づくため，酵 素法で測定を行っている日本の医療機関で使用す る場合には補正が必要とされていたが，2006 年 には特異的測定法である同位体希釈質量分析 （isotope dilution mass spectrometry: IDMS）法によ るScr 值に対応した式（IDMS-MDRD 式）も発

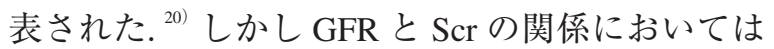
人種も1つの影響因子となることから, IDMSMDRD 式を日本人に適用する際には民族係数を 乗じなければならない。そこで日本腎臓学会は, 日本人でのより正確な推算を目指して日本人の 
データに基づく「日本人の GFR 推算式」を構築 するプロジェクトを立ち上げ， 2008 年に完成した

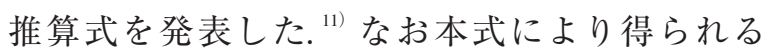
eGFR は標準体表面積あたりの值 $\left(\mathrm{mL} / \mathrm{min} / 1.73 \mathrm{~m}^{2}\right)$ であるため, 個々の患者の eGFR 值 $(\mathrm{mL} / \mathrm{min} /$ body）を得るには患者の体表面積（BSA）を用い て BSA / 1.73 を乗じなければならない. また婦人科 領域で比較的好んで用いられている Jelliffe 式で得 られる eCLcr 值も標準体表面積あたり $(\mathrm{mL} / \mathrm{min} /$ $\left.1.73 \mathrm{~m}^{2}\right)$ である. 本調查において, 日本人の推算 式にて求めた eGFR 值もしくは Jelliffe 式より求 めた eCLcr 值を用いて Calvert 式により CBDCA 投与量を算出している 71 施設のうち, BSA / 1.73 を乗じて個々の患者の腎機能值 $(\mathrm{mL} / \mathrm{min} / \mathrm{body})$ を求めているのはわずか 29 施設であり，それ以 外の施設においては意図した量の CBDCA が投与 されていない現状が明らかとなった（図 2B）. すなわち体表面積が $1.73 \mathrm{~m}^{2}$ より小さい患者では 過剩投与, $1.73 \mathrm{~m}^{2}$ より大きい患者では過少投与 が行われている.

米国における Scr 測定法は, 2010 年末までに IDMS 法に標準化され（http://nkdep.nih.gov/labevaluation/gfr/creatinine-standardization.shtml/, 2015 年 7 月 7 日), 真の Scr 值が臨床で用いられるよ うになった. しかし標準化への移行過程において CBDCA の過量投与に伴う副作用が全米各地で認 められた．すなわち標準化により Scr 測定值が 0.1 $\sim 0.3 \mathrm{mg} / \mathrm{dL}$ 低下したことから, Cockcroft-Gault 式で得られる eCLcr 值で本来の「 CLcr > GFR」 の関係が成り立つようになり, 今までと同様に Calvert 式の GFR 值に eCLcrを代用すると CBDCA が過剩に見積もられることとなった。 そ こで食品医薬品局（Food and Drug Administration: FDA）は，2010 年 10 月 8 日に本事象への対策とし て Calvert 式に用いる GFR 值の上限を $125 \mathrm{~mL} / \mathrm{min}$ に設定し，AUC 4，5，6 での CBDCA 投与量上限 值をそれぞれ $600 \mathrm{mg}, 750 \mathrm{mg}, 900 \mathrm{mg}$ として使 用するよう通知した（http://www.fda.gov/About FDA/CentersOffices/OfficeofMedicalProductsandTob $\mathrm{acco} / \mathrm{CDER} / \mathrm{ucm} 228974 . \mathrm{htm} /, 2015$ 年 7 月 7 日 ). さらに本通知では, 米国の CBDCA 添付文書 (http://www.fda.gov/ohrms/dockets/ac/05/briefing/
2005-4180b_03_05_Carboplatin\%201abe1\%201-904\%20FDA.pdf/, 2015 年 7 月 7 日）に記載されて いる目標 AUC 值に基づく CBDCA 投与時の安全 性デー夕は実測 GFR 值に基づく投与量であるこ とが併せて説明された。 また米国国立がん研究所 （National Cancer Institute: NCI）のがん治療評価 プログラム (cancer therapy evaluation program: CTEP）は NCI 研究費で実施されている CTEP 管 理下の臨床試験の研究者に対して 10 月 1 日にア クションレターを, そして10月22日にはフォロー アップレターを発出し，CBDCA を含む試験での 過量投与を避けることを目的に (1) Calvert 式の GFR 值は実測もしくは推算式より得ること, (2) FDAの 提示した GFR 上限值 $125 \mathrm{~mL} / \mathrm{min}$ ( GFR +25 の上 限值は $150 \mathrm{~mL} / \mathrm{min}$ ) に準じた最大投与量を設定 すること, (3)筋肉量の少ない患者では GFR 推算 式を用いずに実測することが望ましいこと, (4) Scr 低值の患者では Scrの下限を $0.6 \mathrm{mg} / \mathrm{dL}$ (現在は 0.7 $\mathrm{mg} / \mathrm{dL}$ が推奨）並びに GFR 值上限を $125 \mathrm{~mL} / \mathrm{min}$ とすることなどを実施計画書に追記するよう改訂 の指示を行った（http://ctep.cancer.gov/content/docs/ Carboplatin_Information_Letter.pdf/, 2015年7月7日). 今回の調查において, FDA や NCI/CTEP の通知 に基づく投与量の上限設定を行っている医療機関 は 54 施設（48.2\%）であり（図 3)，その設定值 はこれらに準じていた（表 4).

また CBDCA 治療開始後の腎機能の変化に伴う 用量の再計算について尋ねたところ, 毎回更新(再 計算）しているのが 50 施設（44.6\%)，たまに更 新 (再計算) を行っているのが 13 施設 $(11.6 \%)$, 全く更新を行っていないのは 49 施設 $(43.8 \%)$ であった（図4)。前述の NCI/CTEPによる実施 計画書改訂指示においては, 毒性のために減量す る場合を除き, コースごとの再計算は不要と明記 されており, 標準治療確立のために実施された臨 床試験と臨床現場での乘離が認められた。臨床試 験参加には厳しい基準が設定されているため, 比 較的状態の安定した患者のみが対象となっている 場合が多い. 一方, 日常臨床においては併存症を はじめ様々な背景を有する患者が抗がん薬治療の 対象となることから, 患者の状態を考慮したうえ での用量再計算は否定されるものではない. 
実臨床におけるがん薬物療法では, 当該治療の 有用性が検証された臨床試験での投与法, 休薬や 減量基準，副作用に対する支持療法などを個々の 患者に再現することが基本となる，従って CBDCA 投与時には Calvert 式により用量算出が 行われ，また海外で当該レジメンが検証された臨 床試験に基づけば Cockcroft-Gault 式や Jelliffe 式 より得られる eCLcr 值を Calvert 式の GFR 值に代 用することも当然として行われる。しかしながら 本代用が $「 \mathrm{GFR}=\mathrm{eCLcr} 」 の$ 関倸式が成り立って いた米国の状況下のみで妥当であったことを踏ま えれば，同様の算出法を日本が追随すべきでない ことは明らかである。また海外で構築された Cockcroft-Gault 式や Jelliffe 式, Chatelut 式の日本 人での再現性や適用妥当性は, 人種差や血清クレ アチニン測定法の違いのために不確かであること は言うまでもない，そこで Calvert 式が CBDCA のクリアランスと GFR の相関性に基づく式であ ることを再認識し, 本式に忠実に CBDCA の投与 量を求めることに立ち返れば, 臨床での簡便性も 考慮すると 2008 年に発表された日本人のための GFR 推算式により得られる eGFR を用いることが 理にかなっていると考えられる。またその際には 「BSA／1.73」を乗じて患者個々の eGFR（mL/min/ body）を求めることも推算值の単位を理解して いれば当然のことである。しかしながら本 eGFR 值に基づく CBDCA 用量設定が最も適切であると いう実績は現時点においては存在していない。ま た GFR 推算式は腎機能安定時の使用が前提であ り，その適用には限界があるため，急激に腎機能 が変化している入院患者などでは推算式は用いず イヌリンクリアランス検査法により実測すること が勧められている（http://nkdep.nih.gov/identifymanage/evaluate-patients/estimate-gfr.shtml, 2015 年 7 月 7 日). 一方で Calvert 式もまた欧米人のデー 夕に基づいて構築されていることから, 式の切片 を規定する腎外排泄速度 $25 \mathrm{~mL} / \mathrm{min}$ が日本人に とっては大き過ぎるとして Calvert 式そのものの 日本人への外抻妥当性も疑問視されている. ${ }^{18,21)}$ これらの状況並びに要因を考慮すると, 日本で Calvert 式により CBDCA 投与量を算出するにあ たり，何をどこまで注意して徹底すべきかの回答
は一概には得られない. 従って, これらCalvert 式の問題点を理解したうえで Calvert 式により算 出された初回投与量を過信せず，また薬物血中濃 度や薬物感受性には大きな個人差があることを念 頭に, 個々の患者に抢いて忍容性と初回投与量の 妥当性を評価して対応していくことが安全性のみ ならず有效性確保のためにも必須であり，これは CBDCA に限らず全ての抗がん薬投与における基 本姿勢と言える.

\section{謝 辞}

本実態調査にあたり，ご回答くださったがん専門 薬剤師, がん指導薬椷師の方々に深謝いたします.

\section{利益相反}

開示すべき利益相反はない。

\section{引用文献}

1）日本肺癌学会編, “EBMの手法による肺癌診療 ガイドライン2014年版”, 金原出版, 東京, 2014.

2）日本婦人科腫瘍学会編, “卵巣がん治療ガイドラ イン 2015年版”, 金原出版, 東京, 2015.

3）日本婦人科腫瘍学会編, “子宮体がん治療ガイド ライン 2013年版”, 金原出版, 東京, 2013.

4) Harland SJ, Newell DR, Siddik ZH, Chadwick R, Calvert AH, Harrap KR, Pharmacokinetics of cisdiammine-1,1-cyclobutane dicarboxylate platinum (II) in patients with normal and impaired renal function, Cancer Res, 1984, 44, 1693-1697.

5) Calvert AH, Harland SJ, Newell DR, Siddik ZH, Harrap KR, Phase I studies with carboplatin at The Royal Marsden Hospital, Cancer Treat Rev, 1985, 12, 51-57.

6) Calvert AH, Newell DR, Gumbrell LA, O’Reilly $S$, Burnell M, Boxall FE, Siddik ZH, Judson IR, Gore ME, Wiltshaw E, Carboplatin dosage: prospective evaluation of a simple formula based on renal function, J Clin Oncol, 1989, 7, 1748-1756.

7) Jodrell DI, Egorin MJ, Canetta RM, Langenberg P, Goldbloom EP, Burroughs JN, Goodlow JL, Tan S, Wiltshaw E, Relationships between carboplatin 
exposure and tumor response and toxicity in patients with ovarian cancer, J Clin Oncol, 1992, 10, 520528.

8) Horio M, Orita Y, Comparison of Jaffé rate assay and enzymatic method for the measurement of creatinine clearance, Nihon Jinzo Gakkai Shi, 1996, 38, 296-299.

9) Ando M, Minami H, Ando Y, Saka H, Yamamoto M, Sasaki Y, Shimokata K, Hasegawa Y, Multi-institutional validation study of carboplatin dosing formula using adjusted serum creatinine level, Clin Cancer Res, 2000, 6, 4733-4738.

10）日本腎臓学会 編, “エビデンスに基づくCKD 診 療ガイドライン2009”, 東京医学社, 東京, 2009, pp1-10.

11) Matsuo S, Imai E, Horio M, Yasuda $Y$, Tomita $K$, Nitta K, Yamagata K, Tomino Y, Yokoyama H, Hishida A, Collaborators developing the Japanese equation for estimated GFR, Revised equations for estimated GFR from serum creatinine in Japan, $A m$ J Kidney Dis, 2009, 53, 982-992.

12) Cockcroft DW, Gault MH, Prediction of creatinine clearance from serum creatinine, Nephron, 1976, 16, 31-41.

13) Jelliffe RW, Estimation of creatinine clearance when urine cannot be collected, Lancet, 1971, 1, 975-976.

14) Ohe $Y$, Ohashi $Y$, Kubota K, Tamura T, Nakagawa K, Negoro S, Nishiwaki Y, Saijo N, Ariyoshi Y, Fukuoka M, Randomized phase III study of cisplatin plus irinotecan versus carboplatin plus paclitaxel, cisplatin plus gemcitabine, and cisplatin plus vinorelbine for advanced non-small-cell lung cancer: Four-Arm Cooperative Study in Japan, Ann Oncol, 2007, 18, 317 323.

15) Katsumata N, Yasuda M, Takahashi F, Isonishi S,
Jobo T, Aoki D, Tsuda H, Sugiyama T, Kodama S, Kimura E, Ochiai K, Noda K, Japanese Gynecologic Oncology Group, Dose-dense paclitaxel once a week in combination with carboplatin every 3 weeks for advanced ovarian cancer: a phase 3, open-label, randomised controlled trial, Lancet, 2009, 374, 1331-1338.

16) Chatelut E, Canal P, Brunner V, Chevreau C, Pujol A, Boneu A, Roché H, Houin G, Bugat R, Prediction of carboplatin clearance from standard morphological and biological patient characteristics, J Natl Cancer Inst, 1995, 87, 573-580.

17) Levey AS, Measurement of renal function in chronic renal disease, Kidney Int, 1990, 38, 167-184.

18) Shimokata $T$, Ando $Y$, Yasuda $Y$, Hamada A, Kawada K, Saito H, Matsuo S, Kondo M, Imaizumi K, Hasegawa Y, Prospective evaluation of pharmacokinetically guided dosing of carboplatin in Japanese patients with cancer, Cancer Sci, 2010, 101, 26012605.

19) Levey A, Bosch J, Lewis J, Greene T, Rogers N, Roth D, A more accurate method to estimate glomerular filtration rate from serum creatinine: A new prediction equation, Ann Intern Med, 1999, 130, 461-470.

20) Levey AS, Coresh J, Greene T, Stevens LA, Zhang YL, Hendriksen S, Kusek JW, Van Lente F, Chronic kidney disease Epidemiology Collaboration, Using standardized serum creatinine values in the Modification of Diet in Renal Disease Study equation for estimating glomerular filtration rate, Ann Intern Med, 2006, 145, 247-254.

21) Ando Y, Shimokata T, Yasuda Y, Hasegawa Y, Carboplatin dosing for adult Japanese patients, Nagoya $J$ Med Sci, 2014, 76, 1-9. 